\title{
A VÉGREHAJTÓ FUNKCIÓK ZAVARA AFÁZIÁBAN
}

\author{
SZÖLLŐSI IZABELLA ${ }^{1,2}$ - LUKÁCS ÁGNES ${ }^{3}$ - ZAKARIÁS LILLA², \\ ${ }^{1}$ Országos Orvosi Rehabilitációs Intézet; ${ }^{2}$ ELTE Neveléstudományi Doktori Iskola; \\ ${ }^{3}$ Budapesti Műszaki és Gazdaságtudományi Egyetem Kognitív Tudományi Tanszék; \\ ${ }^{4}$ Institut für Linguistik, Universität Potsdam, Deutschland \\ E-mail: i.szollosi@rehabint.hu
}

Beérkezett: 2014. augusztus 4. - Elfogadva: 2014. november 4.

Háttér és célok: Újabb eredmények szerint afáziában a nyelvhasználati képesség diszfunkciójához a végrehajtó funkciók zavara is társulhat. A végrehajtó funkciók a nyelvi feldolgozórendszer müködésében is szerepet játszhatnak. Kutatásunkban afáziával diagnosztizált személyeknél vizsgáltuk a munkamemória frissítését és két gátlófunkciót (a válaszalapú konfliktus és a reprezentációs konfliktus feloldását), illetve ezek összefüggését a nyelvi teljesítménnyel.

Módszer: A vizsgálatban nyolc afáziával diagnosztizált, a frontális lebeny sérülését mutató személy, illetve a hozzájuk korban, nemben és iskolázottságban illesztett egészséges kontrollszemély vett részt. A végrehajtó funkciók vizsgálatára három feladatot használtunk: a Stop Signal, a Nem-verbális Stroop- és az N-back feladatokat. A nyelvi képességeket az afázia diagnosztikájában általánosan alkalmazott teszteken kívïl a TROG Nyelvtani Szerkezetek Megértése teszttel mértük.

Eredmények: Eredményeink a válaszalapú konfliktus gátlásának és a munkamemória frissítésének zavarát mutatták afáziában. Tendenciaszintü összefüggést találtunk a nyelvtani szerkezetek megértése és a munkamemória frissítése között, nem találtunk azonban öszszefüggést a megértés és a gátlási mutatók között.

Konklúzió: Afáziában a frontális lebeny sérülése esetén a nyelvi problémák mellett a végrehajtó funkciók, azon belül a válaszalapú konfliktus feloldásának és a frissítési folyamatoknak, illetve a munkamemória megtartó funkciójának sérülése is megfigyelhetö. A frissitési funkciók sérülése a nyelvi feldolgozórendszer müködését is érintheti.

Kulcsszavak: végrehajtó funkciók, afázia, gátlás, frissítés, nyelvi megértés, munkamemória 


\section{BEVEZETÉS}

Az afázia agyi infarktus, traumás agysérülés vagy agydaganat következtében kialakuló, organikus eredetű, szerzett multimodális diszfunkció, amely a már kialakult felnőtt nyelvi képességstruktúra zavarát eredményezi. A zavar multimodális jellege abban nyilvánul meg, hogy érintheti a nyelv különböző modalitásait: a produkciót, megértést, utánmondást és megnevezést is. A zavar eltérő deficitmintázatokat létrehozva megjelenhet a beszélt és írott nyelvben (SzENTKUTI-KISs, 2010 alapján). A nyelvi feldolgozó rendszer sérülése érintheti a nyelv produkciós és/vagy értési oldalát, illetve hatása megjelenhet a nyelvi szintek mindegyikén: sérülhetnek a fonológiai, szemantikai-lexikális, szintaktikai-grammatikai, pragmatikai nyelvi reprezentációk. Az afáziával diagnosztizált személynek nehézséget jelent a nyelvi információ feldolgozása, aminek következtében a nyelvi produkciót a szókeresés, kommunikációs gátoltság, fragmentált nyelvi szerkezetek jellemezhetik, a megértésben pedig szintaktikai hibákat érhetünk tetten. Az egyes afáziáknak több megjelenési formája lehet, pl. a beszédprodukció minősége széles skálán mozoghat, társuló tünet lehet az agrammatizmus vagy a perszeveráció, de megjelenhet ezek nélkül is.

Az afáziát a XIX. századtól kezdve sokáig a nyelv izolált sérülésének tekintették, melyben a többi megismerő folyamat, mint az észlelés, a figyelem és a memória, nem érintett. E szerint a felfogás szerint a szerzett nyelvi zavarokban a megértés és a produkció egyes komponensei sérülnek, míg mások megőrzöttek, és a sérült-megtartott komponensek különféle variációi eredményezik a kórképre jellemző tüneti sokszínűséget (WHITwORTH, WEBSTER és HOWARD, 2014). Újabb eredmények szerint azonban az afáziás személyek jelentős csoportjánál nem csupán a nyelvi folyamatok, hanem egyes pszichológiai kontrollfunkciók, azaz a végrehajtó funkciók is érintettek. A végrehajtó funkciók zavara a nyelvi folyamatok működésére, a nyelvi zavar és az afáziás tünetek megjelenésére is hatással van (Novick, Trueswell és Thompson-Shill, 2005, 2010; NOvick, Kan, Trueswell és Thompson-Shill, 2009; Penn, Frankel, Watermeyer és Russel, 2010; RoBINSON, BLAIR és CIPOLOTTI, 1998).

\section{Végrehajtó funkciók}

A végrehajtó funkciók kifejezés nem egy egységes funkciót jelöl; olyan képességek összességét jelenti, melyek a specifikusabb kognitív folyamatokat koordinálják a célirányos cselekvések érdekében (MiYake, Friedman, EMERSON, WiTzKi, HOWERTER és WAGER, 2000). Múködésük főként újszerű, döntéshozatalt igénylő helyzetekben kifejezett (BANICH és mtsai, 2000). A végrehajtó funkciók közé sorolják többek között a szelektív és a megosztott figyelem képességét, a figyelmi váltást, a gátlást, az interferencia feloldását, a frissítést és az önmonitorozást. E funkciókat főként a prefrontális kéreg működésével kapcsoljuk össze (a végrehajtó funkciók részletes lokalizációjával kapcsolatban lásd BOTVINICK, COHEN és 
Carter, 2004; Smith, Jonides, Marshuetz és Koeppe, 1998). Miyake és munkatársainak modellje (2000) alapvetően a végrehajtó funkciók három komponensét különbözteti meg, melyek bár viselkedéses és idegrendszeri szinten is elkülöníthetők egymástól, számos feladat során valószínűleg szorosan együttműködnek. A frissités komponense a bejövő információk monitorozásáért és a munkamemóriában tárolt elemek frissítéséért felel, ami a munkamemóriában tárolt irreleváns információ cseréjét jelenti a feladat szempontjából releváns, új információra. A modell második komponense a váltás, ami a feladatok közötti váltást képességét takarja. A gátlás folyamata a bejövő információk versengése esetén a versengés feloldását és az automatikus, domináns választendenciák legátlását teszi lehetővé. Amellett, hogy Miyake modellje talán a legismertebb, a végrehajtó funkciók teljes listája és egymáshoz való viszonya viták tárgyát képezi (FRIEDMAN és MIYAKE, 2004).

\section{Az afáziák és végrehajtó funkciók kapcsolata}

Az afáziák hátterében számos agyterület sérülése állhat, melyek nagymértékben átfedhetnek a végrehajtó funkciókkal is kapcsolatba hozott agyterületekkel. Az afáziák tipológiai felosztása, azaz a két nagy afáziatípus elnevezése is utal a nyelvi zavar hátterében feltételezett sérült területek elhelyezkedésére; elülső/anterior hátulsó/poszterior típusú, vagy másképpen non-fluens - fluens afáziák. Az afázia diagnosztikus profiljának meghatározásában a fluenciát az átlagos frázishossz, vagyis a két szünet közötti, jelentősebb szünet nélkül produkált szavak száma határozza meg. Fluens beszédről 9 vagy több szóból álló átlagos hosszúság esetén, non-fluens beszédről 0-5 szó esetén beszélünk. Határesetet képez a 6-8 szóból álló terjedelem. A dorzolaterális prefrontális terület (Br. 45, 46, 9), a Broca-területet is magában foglaló ventrolaterális prefrontális terület (Br. 44, 45, 47), az ezek alatt található fehérállományi területek, valamint a kiegészítő motoros terület (Br. 6, 32) sérülése legtöbbször non-fluens afáziák megjelenéséhez, vagyis a kifejező beszéd zavarához vezet (például beszédindítási nehézséghez, az ismétlés vagy utánmondás zavarához és a non-fluenciához). Ezeknek a területeknek a sérülése azonban nem csak nyelvi zavar megjelenését okozhatja, hiszen a végrehajtó funkciók megfelelő működése ugyancsak a prefrontális területek ép működésén és annak más agyterületekkel történő megtartott kapcsolatán alapul.

A nyelvi zavar és a végrehajtó funkció zavarok kialakulásához vezető sérült agyterületek közötti átfedés ismeretében nem meglepő, hogy számos kutatás szerint afáziához sok esetben a végrehajtó funkciók zavara is társul (PURDY, 2002; ARdila, 2010; RAMSBERGER, 2005; Helm-EstabroOKS, 2004; ZAKARIÁs, KereSZTES, DEMETER és LUKÁCS, 2013). Az eredmények arra utalnak, hogy nem csupán társult sérülésről van szó; a végrehajtó funkció zavaroknak gyakran oki szerepet tulajdonítanak bizonyos nyelvi nehézségek megjelenésében. A következőkben áttekintett kutatások az afáziában megjelenő tünetek egy-egy csoportjára fókuszálva írják le a végrehajtó funkciók lehetséges szerepét a nyelvi tünetek kialakulásában. 
Végrehajtó funkciók és funkcionális kommunikáció afáziában

Több, afáziás személyek körében végzett vizsgálat is hangsúlyozza a végrehajtó funkciók szerepét a sikeres kommunikációban és a társalgásban (GREEN és mtsai, 2010; Frankel, Penn és Ormond-Brown, 2007; Penn, Frankel, Watermeyer és RUSSEL, 2010; RAMSBERGER, 2005). E tanulmányok szerint a végrehajtó funkciók összefüggést mutatnak az olyan narratív diskurzus és társalgás során alkalmazott képességeinkkel, mint a társalgási fókusz fenntartása, új témák kezdeményezése, a kommunikációs teljesítmény tervezése és monitorozása, illetve a kommunikációs stratégiák közötti váltás (RAMSBERGER, 2005; PENN és mtsai, 2010). A gátlóképességek sérülése esetén az afáziás személyeknek nehézségük adódhat a nem hatékony kommunikációs stratégiák felismerésében és leálításában, a társalgási fókusz és a kommunikációs cél fenntartásában a zavaró elemekkel szemben, és a kevésbé releváns információk gátlásában. A munkamemória sérülése esetén a társalgás idői szervezésében, az új információk aktuális kommunikációs tartalmakba történő integrálásában jelentkezhet nehézség.

\section{Végrehajtó funkciók és lexikális elöhivás afáziában}

Számos tanulmány jutott arra a következtetésre, hogy afáziában a lexikális kiválasztás területén jelentkező nehézségek egy része magyarázható a végrehajtó funkciók sérülésével (ALEXANDER, 2006; LURIJA, 1973; ROBINSON és mtsai, 1998; NOvick és mtsai, 2009). Robinson és munkatársai (1998) egy olyan személyről számoltak be, akinek spontán beszéde szegényes volt, ezzel szemben jó konfrontációs megnevezési képességgel, jó ismétlési és beszédmegértési képességgel rendelkezett. A személy kifejezett nehézsége a szóelőhívás zavara volt, ami azonban a vizsgálatok során csak akkor jelentkezett, amikor a bemutatott inger több lehetséges választ generált, ezzel versengést idézve elő a lexikai reprezentációk között (például amikor a feladata az volt, hogy a vizsgálatvezető által megkezdett mondatot egy szóval fejezze be, a mondatnak azonban több lehetséges és egyaránt valószínủ befejezése lehetett - például a férfi evett egy szendvicset és... mondat esetében). Ezzel szemben, amikor a bemutatott inger feltehetően csak egyetlen választ aktivált - a prepotens válasz gátlása nem volt szükséges - a szóelőhívás megfelelő volt (például a férfi megvette a szendvicset és... mondat befejezése esetén). A jelenséget magyarázó elméletek szerint a nyelvfeldolgozás és produkció során egyidejűleg több reprezentáció is aktiválódhat a szemantikus rendszerben, ami a nyelvi információk átmeneti versengéséhez vezet. A gátló folyamatok teszik lehetővé, hogy az így létrejövő konfliktust detektáljuk, a versengést feloldjuk és a megfelelő szót előhívjuk (Botvinick, Carter, Braver, Barch és Cohen, 2001; Damian, Viglocco és LEVELT, 2001).

\section{Végrehajtó funkciók és mondatfeldolgozás afáziában}

A végrehajtó funkciók zavarai a mondatfeldolgozás és mondatmegértés folyamatára is hatással lehetnek afáziában (THOMPSON-SHILL, 2005), hogy ha a feldolgo- 
zandó mondatok nyelvtanilag komplexek. Az afáziás személyek számára tipikusan nehéznek bizonyuló szintaktikai szerkezetek feldolgozási nehézségeit is magyarázzák a munkamemória-kapacitás csökkenésével és végrehajtó funkció zavarokkal (CAPLAN és WATERS, 1999). Ilyen mondatok például a tárgyi vonatkozói mellékmondatok (például kihivta az orvost, akit ajánlott a szomszéd), a középre ágyazott mellékmondatokat tartalmazó szerkezet (például a kutya, amelyik üldözi a macskát, az foltos), vagy a magyarban ritkábban megjelenő passzív szerkezet (például a ruha ki van teregetve). A kapacitáselméletek amellett érvelnek, hogy a sikeres megértéshez a mondat távoli (közbeékelődő szavakkal, például beágyazott mellékmondattal elválasztott) elemeinek szintaktikai jellemzőit a munkamemóriában (MM) kell tárolnunk, amíg azt integrálni nem tudjuk. A gátlási elméletek szerint, ilyen esetekben a közbeékelődő elemek versengő reprezentációit is gátolnunk kell. NOvick és munkatársai (2005) például a kognitív kontroll és a gátlófolyamatok szerepét hangsúlyozzák valamennyi olyan nyelvfeldolgozást és produkciót igénylő feladatban, amikor az egyértelműsítő információ hiányában versengés alakul ki a reprezentációk között, illetve amikor egy automatikus válasz gátlása szükséges a megfelelő ingerre történő válaszadás érdekében. A mondatmegértés során az esetek többségében az automatikus feldolgozás az inputnak megfelelő nyelvi struktúrát hozza létre, azonban vannak esetek, amikor az automatikus elemzés nem a megfelelő reprezentációk aktivációjához vezet. Ekkor történik a mondat újraanalizálása, amelyben részt vesznek a kognitív kontrollfunkciók, és megtörténik az irreleváns információ elnyomása, illetve az alternatív megoldás kialakítása. Ezt hangsúlyozza az a nyelvi és pszichológiai komponenseket is beépítő komputációs modell is (LEWIS, VASISTHS és VAN-DYKE, 2006), amely szerint a mondatfeldolgozásban az emlékezeti folyamatok (kódolás, megtartás és előhívás) és a gátlófolyamatok egymással együttműködve garantálják a sikeres megértést, ezért bármelyik működés zavara problémát eredményezhet a mondatmegértésben.

\section{A végrehajtó funkciók szerepe az afáziás tünetek alakulásában}

A fentebb áttekintett neuropszichológiai és kísérleti pszichológiai tanulmányok alapján úgy tűnik, hogy a végrehajtó funkciók sérülése a nyelvi teljesítményt negatívan befolyásolhatja, sőt a végrehajtó funkciók zavarai a különböző afáziatípusokban megjelenő eltérő tünetmintázathoz is hozzájárulhatnak (ALEXANDER, 2006; ARDILA, 2010; ZAKARIÁS és mtsai, 2013). Ezt látszik alátámasztani az az eredmény, amely szerint transzkortikális motoros afáziában (TMA) és vezetéses afáziában egyaránt megjelenhetnek végrehajtó funkció zavarok, de a végrehajtó funkciók sérülései eltérő mintázatot mutatnak a két afáziatípusban (ZAKARIás és mtsai, 2013). A TMA a non-fluens afáziák csoportjába tartozik. Leggyakrabban a dorzoés a ventrolaterális prefrontális terület és a kiegészítő motoros terület sérülését követően jelentkezik (ALEXANDER, 2006). Jellegzetes tünete a spontán beszédhez képest szinte megőrzött utánmondás, amelyhez általában jó megértés társul. A spontán beszédben azonban kifejezett az anómia és a perszeveráció, a frázisok rövidsége és a beszéd fragmentáltsága. A vezetéses afázia tünetegyüttese mögött általában a planum temporale terület sérülése áll, melynek következtében akadályozottá vá- 
lik a szenzoros és motoros rendszerek interakciója a beszédprodukcióban, és zavart szenvedhet a fonológiai rövidtávú memória is. Vezetéses afáziában jellemző a jó beszédmegértés és fluens spontán beszéd, az utánmondás azonban a spontán beszédhez viszonyítva súlyosan sérült. A szerzők feltételezése szerint a végrehajtó funkció zavarok eltérő mintázata különböző nyelvi tünetekkel hozhatóak összefüggésbe a két afáziatípusban: a TMA-ban jelentkező szótalálási nehézség és nonfluencia a gátlási funkciók zavarával, a vezetéses afáziában jelentkező utánmondási nehézség pedig a MM-kapacitás sérülésével állhat összefüggésben (ZAKARIÁs és mtsai, 2013).

Tanulmányunkban frontális sérülést mutató afáziával diagnosztizált személyek csoportjában vizsgáltuk a végrehajtó funkciók mủködését. Alapvetően két végrehajtó folyamatra, a munkamemória frissítésére és a gátlásra koncentráltunk, ezek vizsgálatára három végrehajtó funkció feladatot választottunk. A munkamemória frissítését a klasszikus N-back feladattal teszteltük. Mivel a gátlófolyamatokat nem tekinti egységesnek az irodalom - megkülönbözteti egymástól a válaszalapú konfliktus gátlásának és a reprezentációs konfliktus gátlásának képességét (részletesen lásd NOVICK és munkatársainak elméletét, 2005) - választásunk a válaszgátlást vizsgáló Stop Signal (VERBRUGGEN és LOGAN, 2008) és a reprezentációs konfliktuson alapuló gátlást vizsgáló Stroop- (STROOP, 1937; FriedMAN és MiYaKe, 2004; SAlthouse, AtKinson és Berish, 2003) feladatra esett. Az afáziát jellemző beszédzavar miatt, a Stop Signal feladatban megfelelően jelöltük a billentyűket, a Stroop-feladatban pedig a szóolvasás elkerülése érdekében a feladat nem-verbális típusát alkalmaztuk.

\section{HIPOTÉZISEK}

1. Feltételeztük, hogy a frontális lebeny sérülését is mutató afáziás személyek teljesítménye a munkamemória frissítését és a gátlást vizsgáló feladatokban egyaránt elmarad az egészséges kontrollcsoportétól.

2. Feltételeztük továbbá, hogy az afáziás személyek csoportjában összefüggést találunk a mondatmegértés képessége és a munkamemória frissítése (NOVICK és mtsai, 2005, 2010), illetve a mondatmegértés és a gátlófolyamatok között (THOMPSON-SHILL, 2005).

$\mathrm{Az}$ afáziás csoport nyelvi tüneteinek és a lézió helyeinek viszonylagos heterogenitása miatt szeretnénk kiemelni, hogy eredményeink csak iránymutató jellegủek lehetnek, és reméljük, hogy a végrehajtó funkciók és a nyelvi tünetek további célzottabb vizsgálatait inspirálják majd az afáziák különböző típusaiban.

\section{VIZSGÁLATI SZEMÉLYEK}

A vizsgálatban 8 afáziával diagnosztizált személy és a hozzájuk nemben, korban és iskolázottságban illesztett személyekből álló kontrollcsoport vett részt (részletes adataikat az 1. táblázat tartalmazza). Az agyi infarktus lokalizációjára vonatkozó 
1. táblázat. A vizsgálati személyek neurolingvisztikai és demográfiai adatai

\begin{tabular}{|l|c|c|c|c|}
\hline \multirow{2}{*}{} & \multicolumn{2}{|c|}{ Afázia } & \multicolumn{2}{c|}{ Kontroll } \\
\cline { 2 - 5 } & Átlag & Min-Max & Átlag & Min-Max \\
\hline Kor (években) & 54,38 & $43-72$ & 53,38 & $45-69$ \\
\hline Iskolázottság (években) & 13,50 & $8-17$ & 13,88 & $8-16$ \\
\hline WAB teszt (AQ) & 52,55 & $17,4-76,6$ & & \\
\hline TOKEN-teszt (pontszám) & 16,88 & $2-30,5$ & & \\
\cline { 1 - 3 } Boston-megnevezési teszt (Z érték) & $-7,65$ & $-11,63-0,47$ & & \\
\hline
\end{tabular}

információkat a rendelkezésre álló CT felvételekből nyertük (Függelék 1. táblázat). Mindegyik afáziát mutató személy sérülése érintette a prefrontális területeket, azonban előfordult, hogy a frontális területeken kívül más agyi területek is sérültek. A vizsgálati személyeket a Western-afáziateszttel (Western Aphasia Battery, WAB) diagnosztizáltuk. (A teszteken elért részletes pontszámokat a Függelék 1. táblázata tartalmazza.) Emellett kiegészítő tesztként alkalmaztuk a Token-féle beszédmegértést vizsgáló standard tesztet, illetve a Boston-megnevezési tesztet. (A ponthatárokat, övezeteket a Függelék 2., 3. táblázatai tartalmazzák.) A Boston-tesztben kapott $\mathrm{Z}$ érték azt mutatja meg, hogy a beteg teljesítménye milyen mértékben (hány szórásnyira) tér el a saját életkori és iskolázottsági csoportjától. A WAB osztályozása szerint 1 személy transzkortikális motoros afázia, 1 Wernicke-afázia, 5 Broca-afázia, 1 anomikus afázia tünetcsoportját mutatta. A vizsgálatokat az OORI (Országos Orvosi Rehabilitációs Intézet) Hemiplégia osztályán végeztük az intézmény főigazgatójának hozzájárulásával. A 8 személyből álló kontrollcsoport egyik részét önkéntesek, másik részét pedig, az OORI Paraplégia osztályának betegei alkották, akiknek kizárólag alsó végtagi mozgáskorlátozottsága volt, nyelvi és kognitív tüneteket nem mutattak.

\section{VIZSGÁLATI MÓDSZEREK}

\section{TROG teszt (Nyelvtani szerkezetek megértése teszt)}

Az eljárás a nyelvtani szerkezetek megértését vizsgálja. A teszt 80 tételt tartalmaz 20 blokkban. Egy blokk egy adott nyelvtani szerkezet megértését vizsgálja. (A vizsgált szerkezeteket a Függelék 4. táblázata tartalmazza.) Minden blokkba 4 tétel tartozik. A vizsgálati személynek minden tétel esetében 4 kép közül kell rámutatással kiválasztania azt, amelyről a vizsgálatvezető beszél.

Instrukció: „A papiron 4 képet lát. Mutasson rá arra, amelyikröl beszélek!”

Az értékelésnél a teljesített blokkok számát vesszük figyelembe. Akkor értékelünk teljesítettnek egy blokkot, ha a vizsgálati személy mind a négy tétel esetén rámutatott a helyes képre. Ebből a blokkot alkotó nyelvtani szerkezet megtartottságára következtetünk (LUKÁCS, GYŐRI és RÓZSA, 2012). 


\section{Stop Signal feladat}

A Stop Signal feladat (VerbrugGan és LOGAN, 2008; VerbrugGAN és mtsai, 2008) a prepotens válasz gátlásának (vagy másképpen a válaszalapú konfliktus feloldásának) vizsgálatára alkalmas eljárás. Az általunk készített verzió VERBRUGGAN és munkatársai (2008) leírásán alapul. A vizsgálati személyek a számítógép előtt ülnek, melynek képernyőjén egy kört vagy egy négyzetet látnak egy fixációs kereszt megjelenése után. Abban az esetben, ha kör jelenik meg a „C”, ha négyzet jelenik meg a „B” billentyűt kell megnyomniuk, kivéve akkor, ha a forma megjelenése után egy sípoló hangot hallanak, ekkor ugyanis nem szabad nyomniuk semmit. A vizsgálati személyek azt az instrukciót kapják, hogy amennyiben sípoló hangot hallanak, ne nyomják le egyik billentyűt sem (Stop Signal), más esetekben azonban minél gyorsabban és pontosabban válaszoljanak a célingerre. A kísérlet során az instrukció magyarázatára különös hangsúlyt fektettünk az afáziásoknál, és abban az esetben folytattuk a vizsgálat felvételét, ha meggyőződtünk arról, hogy értik a feladatot.

A vizsgálati személyeknek alkalmazniuk kell a motoros gátlást ahhoz, hogy a vizuális inger (kör vagy négyzet) utáni hanginger hallatán ne adjanak választ a gomb lenyomásával. A feladat 15 percet vesz igénybe.

A vizsgálat 7 blokkból áll, melyek a vizuális inger megjelenése és válaszgátlásra figyelmeztető sípszó elhangzása között eltelt időben különböznek egymástól: ez az idő (SOA-Stimulus Onset Asynchrony) 50 és 350 ms között változik, blokkonként 50 ms-mal emelkedve. A blokkok között szünetet tarthatnak a vizsgálati személyek, majd az ENTER billentyủ megnyomásával folytathatják a feladatot. Egy blokkban 60 inger jelenik meg, 30 kör és 30 négyzet véletlenszerủ sorrendben. A 60 ingerből 15 után következik sípolás. A blokkok meghatározott, SOA szerint növekvő sorrendben követik egymást. A vizsgálati személyek az inger megjelenését jelző fixációs keresztet 250 ms-ig látják a képernyőn, a válaszadásra $2000 \mathrm{~ms}$ áll a rendelkezésükre. A klaviatúrán kiemelten jelöltük a két célbillentyűt, hogy elkerüljük az afáziások esetében a betűk tévesztésének a problémáját. A jelölést a kontrollcsoport vizsgálatánál is megtartottuk.

A feladat az E-prime programmal készült, mely rögzítette a válaszokat és a reakcióidőket. A nagyobb késleltetéseknél nehezebb a már eltervezett/elindított választ legátolni, ezért az utolsó 350 ms-os késleltetést tartalmazó blokkban a legnehezebb a válasz kivitelezését gátolni. Az elvárások szerint itt a legkisebb a sípszó utáni helyes elutasítások száma. A helyes elutasítások magasabb száma hatékonyabb gátlási képességekre utal.

\section{Nem-verbális Stroop-feladat}

A Nem-verbális Stroop-feladat a versengő reprezentációk gátlásának vizsgálatára alkalmas eljárás. A feladat klasszikus verziójában színnevek jelennek meg a jelentésüknek megfelelő vagy annak ellentmondó színnel nyomtatva (STROOP, 1935). Mivel afáziában gyakran olvasási problémák is jelentkeznek, a hagyományos elrendezés helyett az E-prime kísérlettervező szoftverrel kialakítottunk egy olyan 
nem-verbális változatot, amely nem támaszkodik az olvasási készségekre. A program az előző feladathoz hasonlóan megjelenítette a feladatot és regisztrálta a válaszokat. A vizsgálati személyek egy számítógép előtt ülnek, és gombnyomással kell válaszolniuk az adott ingerre. A képernyőn nyilak jelennek meg, melyek iránya néha eltér a képernyőn elfoglalt pozíciójuktól. A vizsgálati személyeknek a nyilak irányának megfelelő kurzorbillentyűt (nyilat) kell megnyomniuk minél gyorsabban és pontosabban.

Instrukció: Nyilakat fog látni a képernyön. Az a feladata, hogy a nyilak irányának megfelelö gombot nyomja meg a billentyüzeten!

A feladat három feltételt tartalmaz, melyek egymás után következnek. A kontrollfeltételben a nyilak a képernyő közepén jelennek meg. A kongruens feltételben a nyilak a képernyő négy különböző oldalán (fent, lent, jobb oldalon, baloldalon) jelennek meg, irányuk megegyezik a megjelenésük helyével (például a jobb oldalon megjelenő nyíl jobbra mutat). Az inkongruens feltételben a nyilak szintén a képernyő négy oldalán jelennek meg, azonban az irányuk az oldalon levő pozíciójukkal ellentétes (például a képernyő tetején jelenik meg a lefelé mutató nyíl, vagy a jobb oldalán a balra mutató nyíl). Egy blokk 60 próbát tartalmaz. A feladatsor elején 10 gyakorló feladattal hangolódhatnak rá a vizsgálati személyek a vizsgálatra. Minden esetben megjelenik egy fixációs kereszt a képernyő közepén, mely 500 ms-ig látszódik. Az inger megjelenésétől kezdve 3000 ms áll rendelkezésre válaszolni, majd megjelenik a következő inger. A 3 blokk között szünetet tarthatnak a vizsgálati személyek. Hatékony gátlás esetén a személyek az inkongruens blokkban is keveset hibáznak, ugyanakkor a gátlás költségét tükrözve itt a reakcióidő megnyúlik a kontroll- és kongruens feltételekhez képest.

\section{$N$-back feladat}

Az N-back feladat a komplex munkamemória mérőeljárása, amely több munkamemória-folyamat vizsgálatára alkalmas. Általában a munkamemória reprezentációinak frissítési funkcióját vizsgálják vele, de információt szolgáltathat a munkamemória megtartó képességéről, illetve az ingerek speciális elrendezésétől függően a gátlás hatékonyságáról is. A vizsgálati személyek egymást követően felvillanó betűket látnak a képernyő közepén. A vizsgálat két blokkból áll: 1-back (1-et viszsza), 2-back (2-t vissza). Az első blokkban akkor kell gombot nyomni, ha ugyanaz a betű jelenik meg a képernyőn, mint az azt eggyel megelőző. A második blokkban a célinger azt jelenti, hogy ugyanaz a betű jelenik meg a képernyőn, mint az azt kettővel megelőző. A blokkok egyenként 60 próbából állnak, melyben 10 n-back helyzet található (vagyis 10 olyan inger, amely megegyezik az n-nel előtte levővel). A blokkok között körülbelül 1 perc szünetet tarthatnak a vizsgálati személyek. A feladat az E-Prime 2.0 programmal került megjelenítésre.

Instrukció: A következókben betűket fog látni a képernyö közepén! A feladata, hogy abban az esetben, ha a betü, amelyet lát, megegyezik az eggyel elötte megjelenö betüvel, nyomja meg az ENTER billentyüt! Ellenkezö esetben ne nyomjon semmit! 
Azoknál a próbáknál, ahol nincs billentyűnyomás, a betű 2500 ms-ig látható a képernyő közepén, majd a következő inger $500 \mathrm{~ms}$ elteltével jelenik meg. Ezalatt egy fehér hátteret látnak a vizsgálati személyek. Amennyiben a vizsgálati személy megnyomja az ENTER billentyűt, a következő inger a választ követően $500 \mathrm{~ms}$ késleltetéssel jelenik meg a képernyő közepén. Az első blokk letelte után az E-Prime program egy szünetet jelző feliratot ír ki, illetve a következő blokkhoz szükséges instrukciókat mutatja a vizsgálati személyeknek.

A feladatra adott válaszokat az E-Prime program sorrendben regisztrálja. Az eredmények elemzésében két mutatót vettünk figyelembe: a helyes válaszok és a téves riasztások számát. Helyes leütésnek számít, ha a vizsgálati személy helyesen megnyomja az ENTER billentyűt n-back helyzetben, tehát ha a célinger megegyezik az n-nel elôtte levővel. Téves riasztásnak számít, amennyiben a vizsgálati személy lenyomja az ENTER billentyüt, azonban nem volt n--back helyzet, tehát a látott betű nem felel meg az n-nel előtte levőnek. A végleges n-back pontot a helyes leütések számának, illetve a téves riasztások számának különbsége adja.

\section{EREDMÉNYEK}

\section{TROG teszt eredményei}

Az afáziadiagnosztikában általánosan ismert teszteken kívül a TROG teszt megbízható eredményt ad a nyelvi értési funkciókról. A tesztet alapvetően specifikus nyelvfejlődési zavart mutató gyerekek értési képességeinek a vizsgálatára dolgozták ki. Annak ellenére, hogy az afázia vizsgálatára nem általánosan használt eljárás, úgy tűnik, hogy afázia esetén is rendkívül érzékeny vizsgálóeljárásról van szó. Az eltérő szerkezetủ mondatok megértését vizsgálva több dimenzió mentén értékelhetjük az afáziás személyek értési képességeit. A teszt segítségével megismerhetővé válik az értési profil, ugyanis többféle komplexitású nyelvi szerkezet feltérképezését teszi lehetővé.

A TROG teszt értékelésénél a helyes válaszok számát vettük figyelembe. Tehát a tételek esetében helyesnek fogadtuk el a választ akkor, ha a vizsgálati személy megfelelően választotta ki 4 kép közül azt, amelyik az elhangzott mondathoz kapcsolódott. A tételek esetében a maximálisan elérhető pontszám 80 (20 blokk $\times 4$ tétel). A blokkok esetében akkor értékeltünk helyesnek egy blokkot, ha a vizsgálati személy mind a 4 mondathoz megfelelően azonosította a képet. A maximum elérhető pontszám ebben az esetben 20. A csoportátlagok jelentôs különbséget mutatnak a teljesítményben a kontrollcsoport javára (2. táblázat).

2. táblázat. A nyelvi megértést vizsgáló TROG tesztben mutatott teljesítmény az afáziás és a kontrollcsoportban a helyesen megválaszolt blokkok alapján

\begin{tabular}{|l|r|c|}
\hline & Átlag & Szórás \\
\hline Afázia & 5,63 & 3,34 \\
\hline Kontroll & 18,57 & 1,27 \\
\hline
\end{tabular}


Az ismételt méréses varianciaanalízis alapján a Blokk $(\mathrm{F}(19,266)=9,3, p<0,001$, $\left.\eta^{2}=0,4\right)$ és a Csoport $\left(\mathrm{F}(1,14)=53,03, p<0,001, \eta^{2}=0,99\right)$ föhatás is szignifikánsnak bizonyult, és a Blokk $\times$ Csoport interakció is $(\mathrm{F}(19,266)=5,83, p<0,001$, $\eta^{2}=0,29$ ). Az utóelemzésben egy szempontos varianciaanalízissel vizsgáltuk a Csoport hatását az egyes blokkokon mutatott teljesítményre, szignifikáns csoportkülönbséget találtunk az F, G, H, I, J, K, L, M, N, O, P, R, S, T blokkokban. (A pontos statisztikai eredményeket lásd Függelék 5. táblázat.)

Az afáziával diagnosztizált személyek megértési teljesítménye azt mutatja, hogy általában szintaktikailag minél komplexebb volt egy mondat, annál nagyobb nehézséget jelentett annak feldolgozása (1. ábra). Fokozott nehézséget jelentett például az egyes-többes szám (G blokk), középfok-felsőfok (K blokk), téri viszonyokat tartalmazó mondatok (M blokk), középre beágyazott alanyi mellékmondatok ( $\mathrm{N}$ blokk), X, de nem Y szerkezet (O blokk), fölött-alatt viszonyok (P blokk), jobbra beágyazott mellékmondat (R blokk), középre beágyazott tárgyi mellékmondatok (T blokk) feldolgozása, míg ugyanez a szerkezet a kontrollcsoportnak nem okozott problémát. Az afáziás csoport számára közel minden szerkezet megértése problémásnak bizonyult, kivéve a melléknevekből álló szerkezetek ( $\mathrm{C}$ blokk), melyben plafonteljesítményt nyújtottak. Az igék (B blokk), kételemű kombinációk (D blokk) és a nemcsak, de szerkezetek (Q blokk) megértése szintén közelített a kontrollcsoportéhoz. A nyelvtanilag komplexebb beágyazott szerkezetek megértése minden esetben nehézséget jelentett az afáziásoknak. A kontrollcsoport többnyire plafonteljesítményt mutatott, azonban az utolsó három blokkban, amely a jobbra be-

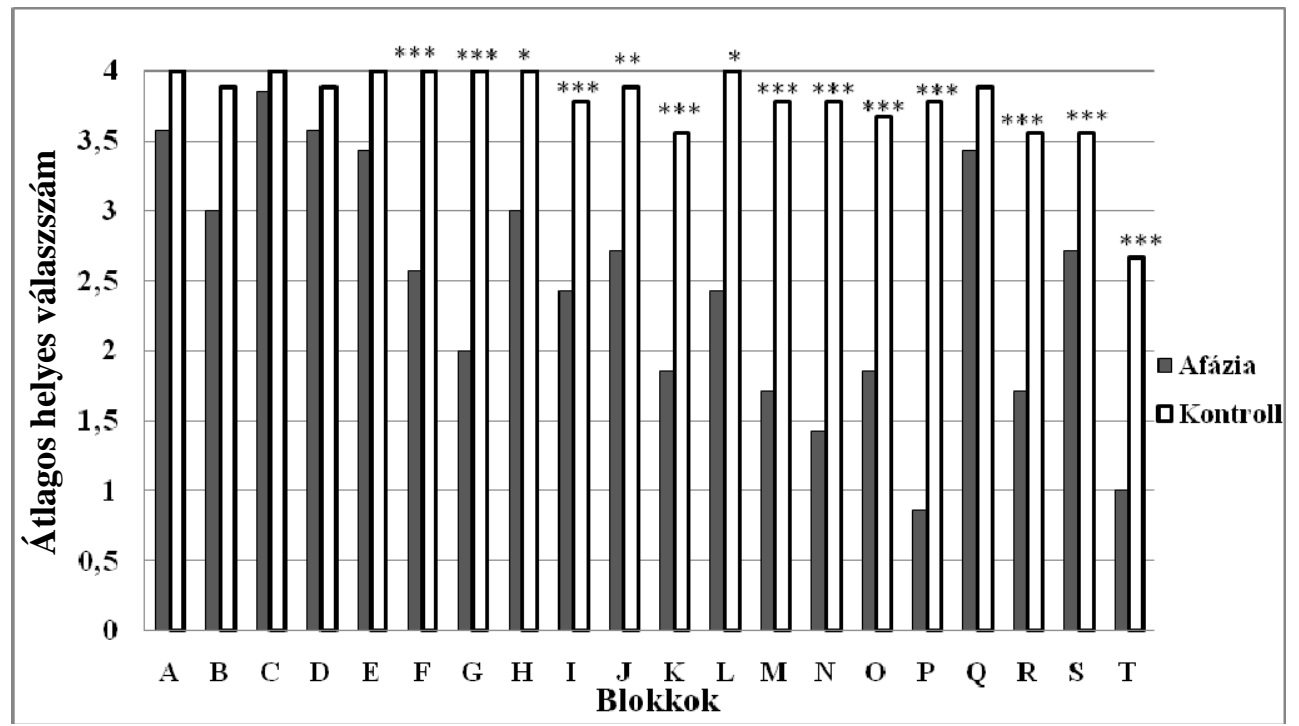

1. ábra. Az afáziás és a kontrollcsoport teljesítménymintázata a nyelvtani szerkezetek megértését vizsgáló TROG tesztben. A helyes válaszok átlagos száma az eltérő szerkezeteket tartalmazó Blokkokban (lásd 1. táblázat). Jelölések: ${ }^{* * *} p<0,001,{ }^{* *} p<0,01,{ }^{*} p<0,05$ 
ágyazott vonatkozó mellékmondatok ( $\mathrm{R}$ blokk), a sem ... sem szerkezetű tagadás ( $\mathrm{S}$ blokk) és a középre beágyazott vonatkozó mellékmondatok ( $\mathrm{T}$ blokk) megértésében már ők is ejtettek hibákat. Az afáziás csoport teljesítménye ezekben a blokkokban is jelentős elmaradást mutatott a kontrollhoz képest.

\section{A Stop Signal feladat eredményei}

Elsőként a sípolás után helyesen kihagyott válaszok számát vettük figyelembe az egyes feltételekben a csoportok közötti összehasonlításnál, ugyanis a Stop Signal feladatban a gátlási mechanizmusok közreműködését leginkább ez a részfeladat igényli. A feltételek a késleltetés idejében különböztek. Az első feltételben $50 \mathrm{~ms}$ telt el a vizuális inger és a hanginger megjelenése között, majd a 7 . feltételig ez az idő 50 ms-mal növekedett minden feltételben. Az ismételt méréses varianciaanalízis alapján szignifikáns Csoport főhatást találtunk $(\mathrm{F}(1,14)=12,35, p<0,01$, $\left.\eta^{2}=0,47\right)$ a helyesen kihagyott válaszok számára (2. ábra): a kontrollcsoport sikeresebb volt a válaszgátlásban, mint az afáziás csoport. A Késleltetés hatása nem volt szignifikáns, és nem volt szignifikáns a Késleltetés $\times$ Csoport interakció $(\mathrm{F}(6,84)=$ 0,83, n.sz). Amikor nem volt stop jelzés, a helyes leütések számában nem találtunk sem szignifikáns Késleltetés főhatást $(\mathrm{F}(6,84)=0,82$, n.sz.), sem Csoport főhatást $(\mathrm{F}(1,14)=0,93, \mathrm{n} . \mathrm{sz}$.$) . Továbbá a Késletetés \times$ Csoport interakció sem bizonyult szignifikánsnak $(\mathrm{F}(6,84)=0,78, \mathrm{n} . \mathrm{sz}$.).

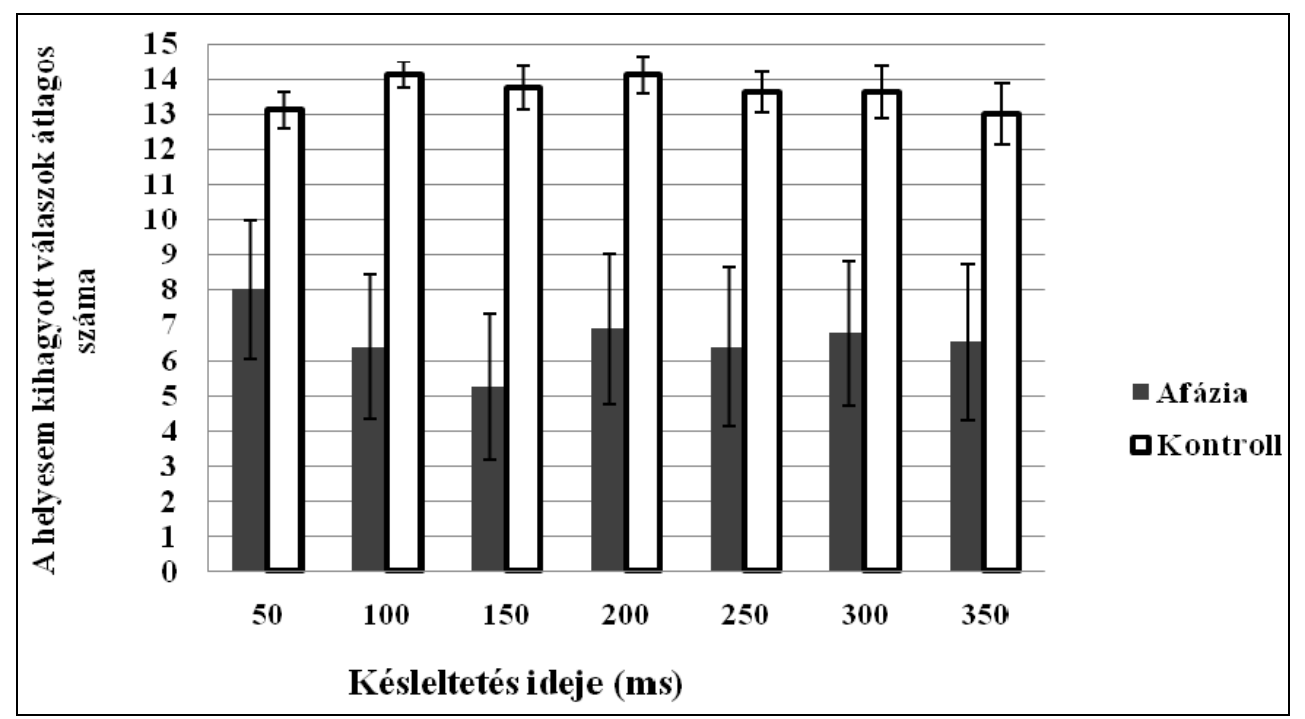

2. ábra. A helyesen kihagyott válaszok átlagos száma $(\max =15)$ a késleltetési idő függvényében a Stop Signal feladatban. Az ábrán látható függőleges vonalak a standard hibát (SE) jelölik 
Ismételt méréses varianciaanalízist alkalmaztunk, Csoport (afáziás és kontrollcsoport) és Feltétel (kontroll - inkongruens - kongruens) faktorokkal. Az elemzések szerint, a Feltétel szignifikáns hatással volt a helyes válaszok számára $(\mathrm{F}(2,28)=$ $\left.3,77, p<0,05, \eta^{2}=0,21\right)$, és a Csoport föhatás is szignifikánsnak bizonyult $(\mathrm{F}(1,14)$ $\left.=9,42, p<0,01, \eta^{2}=0,4\right)$. A Csoport $\times$ Feltétel interakció nem volt szignifikáns $(\mathrm{F}(2,28)=2,47$, n.sz. $)(3$. ábra $)$.

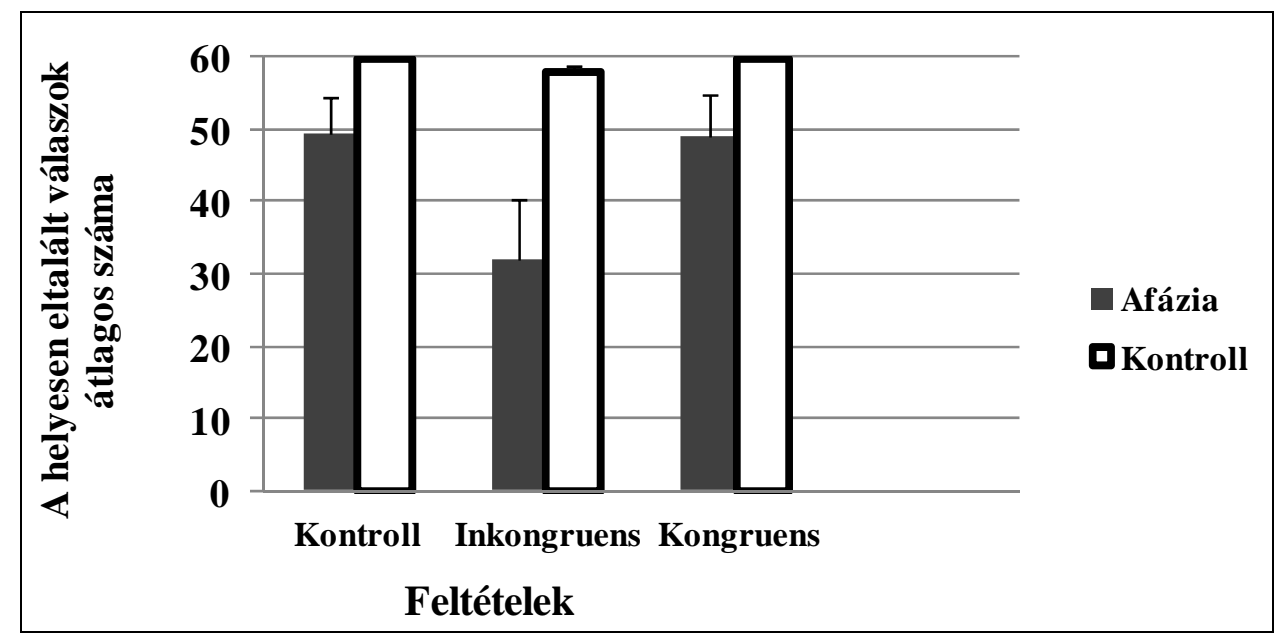

3. ábra. A helyes válaszok átlagos száma feltételenként (max=60) a Nem-verbális Stroop-feladatban. A függőleges vonalak a standard hibát (SE) jelölik

\section{N-back feladat eredményei}

Az N-back feladatban elsőként a végleges n-back pontszámokat vizsgáltuk a csoportok között. Ezt az értéket úgy kaptuk meg, hogy a helyes válaszok számából kivontuk a téves riasztások számát. Így megkaptuk az összetett n-back pontszámot 1-back és 2-back feltételben is. Ismételt méréses varianciaanalízissela Feltétel (1-versus 2-back) × Csoport (afáziás és kontrollcsoport) faktorokat vizsgáltuk. A Feltétel hatása nem volt szignifikáns a helyes válaszok számára $(\mathrm{F}(1,14)=0,98$, n.sz.) és a Feltétel $\times$ Csoport interakció sem $(\mathrm{F}(1,14)=0,07$, n.sz.) bizonyult szignifikánsnak. A Csoport azonban főhatást mutatott az n-back helyzetekre adott helyes válaszok számára $\left(\mathrm{F}(1,14)=8,32, p<0,05, \eta^{2}=0,37\right)$. A csoportközi különbség arra utal, hogy az afáziások kevésbé voltak sikeresek a back-helyzetekre adott válaszadásban.

Kíváncsiak voltunk, hogy a csoportkülönbség a helyes válaszok vagy a téves riasztások arányainak eltérését tükrözi-e. A helyes válaszok számában az ismételt 
méréses varianciaanalízis szerint a Feltétel (1-back, 2-back) szignifikáns föhatást mutatott a teljesítményre $\left(\mathrm{F}(1,14)=13,85, p<0,01, \eta^{2}=0,5\right)$ és a Feltétel $\times$ Csoport interakció is szignifikánsnak bizonyult $\left(\mathrm{F}(1,14)=5,98, p<0,05, \mathrm{\eta}^{2}=0,3\right)$, ahogy a Csoport főhatást is $\left(\mathrm{F}(1,14)=10,93, p<0,05, \eta^{2}=0,44\right)$.

A téves riasztások számára az ismételt méréses varianciaanalízis alapján a Feltétel (1-back, 2-back) faktor $(\mathrm{F}(1,14)=0,72$, n.sz.) nem mutatott főhatást, azonban a Csoport hatása tendenciaszintű volt $\left(\mathrm{F}(1,14)=3,42, p=0,086, \eta^{2}=0,2\right)$. A Feltétel $\times$ Csoport interakció nem bizonyult szignifikánsnak $(\mathrm{F}(1,14)=1,24$, n.sz.).

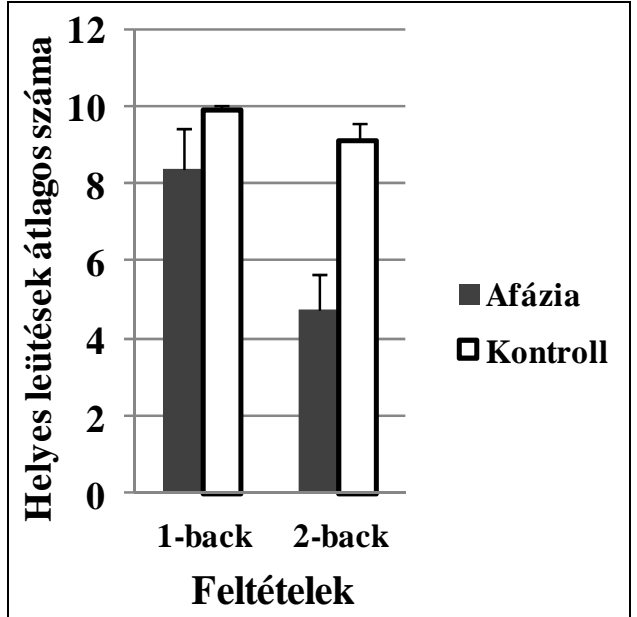

A

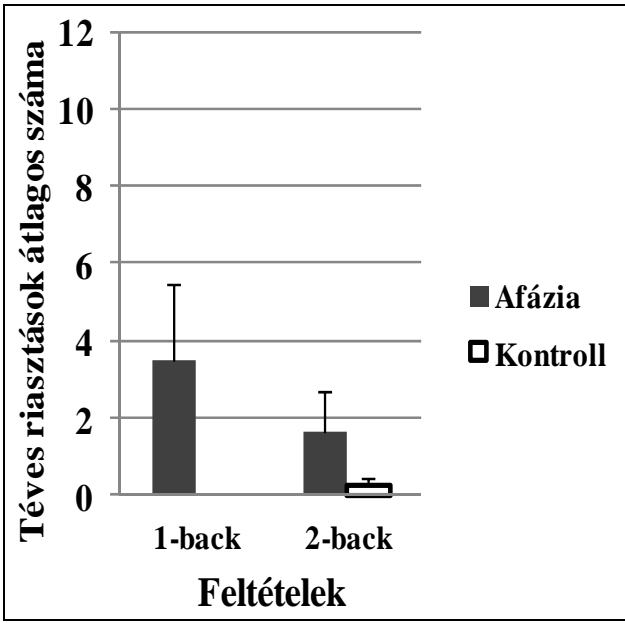

B

4. ábra. A helyes leütések (A) és a téves riasztások (B) átlagos száma csoportonként és feltételenként az N-back feladatban. A függőleges vonalak a standard hibát (SE) jelölik

\section{A végrehajtó funkciók kapcsolata a nyelvi teljesítménnyel}

Kíváncsiak voltunk arra, hogy a végrehajtó feladatokban mutatott eredmények és a nyelvi feladatban mutatott eredmények között kimutatható-e kapcsolat. Ehhez a teljesítmények közötti együttjárásokat vizsgáltuk az afáziás csoportban. A kontrollcsoport TROG feladatban nyújtott plafon közeli teljesítménye miatt nem vizsgáltunk együttjárást a végrehajtó funkciókat vizsgáló feladatokban mutatott eredményeikkel. A végrehajtó funkciók teljesítménymutatóinak összefüggéseit vizsgáltuk a TROG feladatban nyújtott teljesítménnyel: a TROG-ban a helyesen megválaszolt tételek számát, a Stop Signal feladatban a helyes kihagyások (nem nyomott gombot, tehát gátolta a motoros választ akkor, amikor kellett) átlagos számát, a Nem-verbális Stroop-feladatban az inkongruens feltételben adott helyes válaszok számát és az N-back feladatban a végleges n-back pontszámot (az 1- és 2-back pontszám összegét) vettük bele az elemzésbe. A Pearson-féle korrelációs próba 
alapján tendencia szintủ együttjárást találtunk az N-back feladat és a TROG változói között $(r(8)=0,677, p=0,065)$. Nem mutattak együttjárást a Stop Signal feladat és a TROG feladat, illetve a Nem-verbális Stroop és a TROG mutatói.

\section{ÖSSZEGZÉS ÉS KÖVETKEZTETÉSEK}

Vizsgálatunkban afáziás személyek végrehajtó működéseit kívántuk feltérképezni, és arra voltunk kíváncsiak, hogy frontális sérülés esetén a nyelvi tüneteket kíséri-e frissítési és gátlási probléma is. A három végrehajtó funkciót vizsgáló feladat (Stop Signal feladat, Nem-verbális Stroop-feladat, N-back feladat) nem mutatott egységes képet. A Stop Signal feladatban megfigyelhető volt a végrehajtó folyamatok érintettsége az afáziás csoportban a nyelvileg ép kontrollcsoportéhoz képest: a helyesen kihagyott leütések alacsony száma az afáziásoknál (figyelembe véve, hogy a helyes leütések számában nem volt csoportkülönbség) a motoros gátlás sérülésére utal. A Nem-verbális Stroop-feladatban is különbözött a két csoport teljesítménye a kontrollcsoport javára, a teljesítménymintázat azonban hasonló volt, ahogy azt az interakció hiánya mutatja. Vagyis az afáziás csoport egyaránt kevesebb jó választ adott a gátlást igénylő inkongruens és a gátlást nem igénylő kongruens és kontrollfeltételekben, ami a Stroop-feladat esetében a gátlófunkciók specifikus sérülése ellen szól.

Az N-back feladatban a végleges n-back pontszám csoportközi különbséget mutat, amely a munkamemória frissítési képességének a sérülésére utal. A csoporteltérés egyedül a helyes válaszok számában mutatkozott meg, ami a munkamemória megtartó és frissítő képességének sérülésére utal az afáziásoknál.

Eredményeink összhangban vannak azokkal a kutatásokkal, melyek szerint a munkamemória megtartó és frissítő funkciója (NOvicK és mtsai, 2010; BADDELEY, 2003) és a motoros válasz gátlása (Novick és mtsai, 2005) zavart mutathat afáziában. Ugyanakkor - több korábbi tanulmánnyal ellentétben (BIEGLER, CROWTHER és MARTIN, 2008; BROWN-SCHMIDT, 2009) - nem találtunk egyértelmü, a reprezentációs konfliktus feloldásának zavarára utaló eredményt afáziában. A két gátlási feladatban nyújtott eltérő teljesítmény - a kontrollcsoporthoz képest alacsony teljesítmény a motoros válasz gátlását mérő Stop Signal feladatban és a reprezentációs konfliktus gátlásának zavarára utaló eltérés hiánya a Nem-verbális Stroop-feladatban - megerősíti azokat az elképzeléseket, melyek szerint a két feladat valóban eltérő funkciókat vizsgál (Novick és mtsai, 2005).

Feltételeztük, hogy a tanulmányban vizsgált, frontális területeiken érintett páciensek csoportjában összefüggést találunk a végrehajtó funkciók zavara és a mondatmegértés képessége között. A korábbi irodalmi adatoknak megfelelően tendencia szinten megmutatkozott a munkamemória frissítési képessége (N-back feladat) és a nyelvi megértési teljesítmény közötti együttjárás. A várttól eltérően azonban nem találtunk együttjárást sem a Stop Signal feladat, sem pedig a Nem-verbális Stroop mutatói és a TROG teszttel számolt megértési mutató között. Ennek részben az lehet az oka, hogy a TROG teszt egy sztenderdizált eljárás, nem a nyelvi reprezentációk versengésének feloldását vizsgálja, ezért nem meglepő, ha nem 
kifejezetten érzékeny a gátlási folyamatokra. A kapcsolat kimutatásához további vizsgálatok szükségesek (például proaktív interferencia vizsgálatára irányuló eljárások, kétértelműségek feloldásának vizsgálata stb.). Úgy tűnik, hogy a nyelvi rendszer sérülését sérült gátlófunkció-működés, továbbá csökkent munkamemóriakapacitás és sérült frissítés is kísérheti.

Összefoglalva, a válaszalapú konfliktus feloldásának sérülése és a frissítési folyamatok diszfunkciója gyakran megjelenik szerzett nyelvi zavar esetén, vagyis afáziában a sérülés a nyelvi képességstruktúra zavarán kívül magában foglalhatja a kognitív kontrollfolyamatok deficitjét is. A fenti eredmények iránymutató jellegűek, további célzott vizsgálatok szükségesek a gátló funkciók tulajdonságainak, illetve a nyelvi folyamatokkal feltételezett kapcsolatának pontosabb és részletesebb megismeréséhez.

\section{FÜGGELÉK}

1. táblázat. Az afáziás betegek részletes adatai a sérült agyterületek helyére vonatkozóan és a nyelvi tesztekben elért pontszámok személyenként

\begin{tabular}{|c|c|c|c|c|c|}
\hline 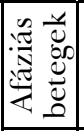 & Léziók helye & WAB (AQ) & $\begin{array}{l}\text { Token-teszt } \\
\text { (pontszám) }\end{array}$ & \begin{tabular}{|c|} 
Boston \\
megnevezési \\
teszt $(\mathrm{Z}$ érték) \\
\end{tabular} & $\begin{array}{l}\text { Afázia } \\
\text { típusa }\end{array}$ \\
\hline 1. & $\begin{array}{l}\text { Kortikális lézió a bal ACM-ben } \\
\text { fronto-temporo-parietális terü- } \\
\text { leten }\end{array}$ & 70,6 & 19 & $-11,16$ & Anomikus \\
\hline 2. & $\begin{array}{l}\text { Hátulsó bal frontális parietális } \\
\text { ischaemiás lézió }\end{array}$ & 32,2 & 12 & $-10,07$ & Wernicke \\
\hline 3. & $\begin{array}{l}\text { A bal ACM területében fronto- } \\
\text { parietális határon ischaemiás } \\
\text { lézió }\end{array}$ & 76,6 & 22,5 & $-3,78$ & Broca \\
\hline 4. & $\begin{array}{l}\text { Bal oldali fronto-parietális agy- } \\
\text { állományi verses }\end{array}$ & 68,4 & 30,5 & $-10,39$ & TMA \\
\hline 5. & $\begin{array}{l}\text { Bal frontális lebenyben laterális } \\
\text { inhomogén hypodenzitás + bal } \\
\text { oldalon, a törzsdúcokat érintő } \\
\text { mély fehérállományban }\end{array}$ & 34,4 & 10 & $-7,8$ & Broca \\
\hline 6. & $\begin{array}{l}\text { Bal kortikális fronto-temporo- } \\
\text { parietális lézió az ACM-ben } \\
\text { érintve a subkortikális régiókat } \\
\text { + bal dorsalis corona radiatát a } \\
\text { centrum semiovale-ban }\end{array}$ & 17,4 & 2 & $-11,06$ & Broca \\
\hline 7. & $\begin{array}{l}\text { Bal fronto-parietális homogén } \\
\text { hypodenzitás }\end{array}$ & 50,2 & 33 & 0,47 & Broca \\
\hline 8. & $\begin{array}{l}\text { Bal ACM fronto-parietális terü- } \\
\text { leten }\end{array}$ & 70,6 & 17,5 & 7,38 & Broca \\
\hline
\end{tabular}


2. táblázat. A WAB teszt övezetei az AQ alapján

\begin{tabular}{|c|c|c|}
\hline WAB övez & & AQ \\
\hline Enyhe & \multirow{4}{*}{ afázia } & $94-75$ \\
\hline Közepes & & $75-50$ \\
\hline Közepesen súlyos & & $50-25$ \\
\hline Igen súlyos & & $25-0$ \\
\hline
\end{tabular}

3. táblázat. Token-teszt ponthatárai

\begin{tabular}{|c|l|}
\hline Pontszám & Értési zavar mértéke \\
\hline $36-30$ & nincs értési zavar \\
\hline $29-25$ & enyhe zavar \\
\hline $24-17$ & közepes zavar \\
\hline $16-9$ & súlyos zavar \\
\hline $8-0$ & igen súlyos zavar \\
\hline
\end{tabular}

4. táblázat. TROG blokkjai és a hozzájuk tartozó nyelvtani szerkezetek

\begin{tabular}{|c|l|l|}
\hline Blokk & \multicolumn{1}{|c|}{ Vizsgált nyelvtani szerkezet } & \multicolumn{1}{c|}{ Tesztszó/Tesztmondat } \\
\hline A & Főnév & Alma. \\
\hline B & Ige & Ül. \\
\hline C & Melléknév & Hosszú. \\
\hline D & Kételemű kombináció & A piros labda. \\
\hline E & Tagadás & A kutya nem ül. \\
\hline F & Háromelemű kombináció & A lány ül az asztalon. \\
\hline G & Egyes/Többes számú személyes névmás & Az elefánt viszi öket. \\
\hline H & Felcserélhető szereplók & A fiú kergeti a bárányt. \\
\hline I & SVO szórend & A ló nézi a lányt. \\
\hline J & Egyes/Többes számú főnévrag & A lány leejti a csészéket. \\
\hline K & Középfok/Felsőfok & A cipó nagyobb, mint a madár. \\
\hline L & OVS szórend & A lányt kergeti a ló. \\
\hline M & Téri ragok (-ban, -ba) & A kés a cipön van. \\
\hline N & Középre beágyazott mellékmondat S-S & A fiú, aki kergeti a lovat, az kövér. \\
\hline O & X de nem Y & A doboz piros, de a szék nem. \\
\hline P & Fölött és alatt & A négyzet a csillag alatt van. \\
\hline Q & Nemcsak X, de Y is & Nemcsak a madár, de a virág is kék. \\
\hline R & Jobbra beágyazott mellékmondat alany-X & A ceruza azon a könyvön van, ami sárga. \\
\hline S & Sem X sem Y & A fiúnak nincs se kalapja, se cipöje. \\
\hline T & Középre beágyazott mellékmondat X-alany & A macska, amit a tehén kerget, az fekete. \\
\hline
\end{tabular}


5. táblázat. A nyelvi megértést vizsgáló TROG teszt blokkjaiban mutatott egy szempontos ANOVA eredményei az afáziás és kontrollcsoport vizsgálatában

\begin{tabular}{|c|r|r|c|}
\hline Blokkok & \multicolumn{1}{|c|}{$\mathbf{F}$} & Sig. & $\eta^{2}$ \\
\hline $\mathbf{a}$ & 2,03 & 0,18 & 0,13 \\
\hline $\mathbf{b}$ & 3,94 & 0,07 & 0,22 \\
\hline $\mathbf{c}$ & 1,00 & 0,33 & 0,07 \\
\hline $\mathbf{d}$ & 3,50 & 0,08 & 0,20 \\
\hline $\mathbf{e}$ & 3,50 & 0,08 & 0,20 \\
\hline $\mathbf{f}$ & 25,00 & 0,00 & 0,64 \\
\hline $\mathbf{g}$ & 22,87 & 0,00 & 0,62 \\
\hline $\mathbf{h}$ & 4,83 & 0,05 & 0,26 \\
\hline $\mathbf{i}$ & 21,72 & 0,00 & 0,61 \\
\hline $\mathbf{j}$ & 9,21 & 0,01 & 0,40 \\
\hline $\mathbf{k}$ & 30,19 & 0,00 & 0,68 \\
\hline $\mathbf{l}$ & 7,63 & 0,02 & 0,35 \\
\hline $\mathbf{m}$ & 81,00 & 0,00 & 0,85 \\
\hline $\mathbf{n}$ & 35,00 & 0,00 & 0,71 \\
\hline $\mathbf{o}$ & 37,80 & 0,00 & 0,73 \\
\hline $\mathbf{p}$ & 20,59 & 0,00 & 0,60 \\
\hline $\mathbf{q}$ & 3,72 & 0,07 & 0,21 \\
\hline $\mathbf{r}$ & 30,88 & 0,00 & 0,69 \\
\hline $\mathbf{s}$ & 12,45 & 0,00 & 0,47 \\
\hline $\mathbf{t}$ & 51,55 & 0,00 & 0,79 \\
\hline
\end{tabular}

\section{IRODALOM}

AleXANDER, M. P. (2006). Impairments of procedures for implementing complex language are due to disruption of frontal attention processes. Journal of the International Neuropsychological Society, 12(2), 236-247.

ARDiLA, A. (2010). A proposed reinterpretation and reclassification of aphasic syndromes. Aphasiology, 24(3), 363-394.

Banich, M. T., Milham, M. P., Atchley, R. A., Cohen, N. I., Webb, A., Wszalek, T., Kramer, A. F., Liang, Z., Barad, V., Gullett, D., Shah, C., \& Brown, C. (2000). Prefrontal regions play a predominant role in imposing an attentional 'set': evidence from fMRI. Cognitive Brain Research, 10(1), 1-9.

Biegler, K. A., Crowther, J. E., \& Martin, R. C. (2008). Consequences of an inhibition deficit for word production and comprehension: Evidence from the semantic blocking paradigm. Cognitive Neuropsychology, 25(4), 493-527.

Botvinick, M. M., Carter, C. S., Braver, T. S., Barch, D. M., \& Cohen, J. D. (2001). Conflict monitoring and cognitive control. Psychological Review, 108(3), 624-652.

Botvinick, M. M., Cohen, J. D., \& Carter, C. S. (2004). Conflict monitoring and anterior cingulate cortex: An update. Cognitive Sciences, 8(12), 539-546. 
BROWN-SchmidT, S. (2009). The role of executive function in perspective taking during online language comprehension. Psychonomic Bulletin \& Review, 16(5), 893-900.

CAPlan, D., \& WATERs, G. S. (1999). Verbal working memory and sentence comprehension. Behavioral and brain Sciences, 22(1), 77-94.

Damian, M. F., Vigliocco, G., \& LeVelt, W. I. (2001). Effects of semantic context in the naming of pictures and words. Cognition, 81(3), B77-B86.

Frankel, T., Penn, C., \& Ormond-Brown, D. (2007). Executive dysfunction as an explanatory basis for conversation symptoms of aphasia: A pilot study. Aphasiology, 21(68), 814-828.

Friedman, N. P., \& Miyake, A. (2004). The relations among inhibition and interference control functions: A latent-variable analysis. Journal of Experimental Psychology, 133(1), $101-135$.

Green, D. W., Grogan, A., Crinion, J., Ali, N., Sutton, C., \& Price, C. J. (2010). Language control and parallel recovery of language in individuals with aphasia. Aphasiology, 24(2), 188-209.

Helm-Estabrooks, N. (2002). Cognition and aphasia: a discussion and a study. Journal of Communication Disorders, 35, 171-186.

Lewis, R. L., VASISTH, S., \& VAN DYKe, J. A. (2006). Computational principles of working memory in sentence comprehension. Trends in cognitive sciences, 10(10), 447-454.

LUKÁCS Á., GYŐRI M. és RÓzSA S. (2012). A TROG pszichometriai jellemzőinek magyar vizsgálata, a normák kialakítása. In D. V. M. BISHOP (Ed.) TROG - Test for Reception of Grammar. Kézikönyv (47-86). Budapest: OS Hungary Tesztfejlesztő Kft.

LUKÁCS Á., GYŐRI M. és RÓZSA S. (2013). TROG-H: új sztenderdizált módszer a nyelvtani megértés fejlődésének vizsgálatára. Gyógypedagógiai Szemle, 61(1), 1-22.

LuRIA, A. R. (1973). The Working Brain: An Introduction to Neuropsychology. New York: Basic Books.

Miyake, A., Emerson, M. J., \& Friedman, N. P. (2000). Assessment of executive functions in clinical settings: Problems and recommendations. Seminars in Speech and Language, 21, 169-183.

Novick, J. M., Trueswell, J. C., \& Thompson-Schill, S. L. (2005). Cognitive control and parsing: Reexamining the role of Broca's area in sentence comprehension. Cognitive, Affective, \& Behavioral Neuroscience, 5, 263-281.

Novick, J. M., Kan, I. P., Trueswell, J. C., \& Thompson-Schill, S. L. (2009). A case for conflict across multiple domains: Memory and language impairments following damage to ventrolateral prefrontal cortex. Cognitive neuropsychology, 26(6), 527-567.

Novick, J. M., Trueswell, J. C., \& Thomspon-Schill, S. L. (2010). Broca's area and language processing: Evidence for the cognitive control connection. Language and Linguistics Compass, 4(10), 906-924.

Penn, C., Frankel, T., Watermeyer, J., \& Russell, N. (2010). Executive function and conversational strategies in bilingual aphasia. Aphasiology, 24(2), 288-308.

Purdy, M. (2002). Executive function ability in persons with aphasia. Aphasiology, 16(4/5/6), $549-557$.

Ramsberger, G. (2005). Achieving conversational success in aphasia by focusing on nonlinguistic cognitive skills: A potentially promising new approach. Aphasiology, 19(10-11), 1066-1073. 
Robinson, G., Blair, J., \& Cipolotti, L. (1998). Dynamic aphasia: An inability to select between competing verbal responses? Brain, 121, 77-89.

Salthouse, T. A., Atkinson, T. M., \& Berish, D. E. (2003). Executive functioning as a potential mediator of age-related cognitive decline in normal adults. Journal of Experimental Psychology: General, 32(4), 566-594.

Smith, E. E., Jonides, J., Marshuetz, C., \& Koeppe, R. A. (1998). Components of verbal working memory: evidence from neuroimaging. Proceedings of the National Academy of Sciences, 95(3), 876-882.

Stroop, J. R. (1935). Studies of interference in serial verbal reactions. Journal of Experimental Psychology, 18, 643-662.

SzENTKUTI-KISS K. (2010). alapján In VeKerdy-NAGY Zs. (szerk.), A verbális kommunikáció zavarai felnöttkori szerzett agysérülés következtében (412-420). Budapest: Medicina.

Thompson-Schill, S. L. (2005). Dissecting the language organ. A new look at the role of Broca's area in language processing. In A. CuTLER (Ed.), Twenty-First Century Psycholinguistics: Four Cornerstone (173-191). Mahwah, NJ: Lawrence Elbraum Associates.

Zakariás, L., Keresztes, A., Demeter, Gy., \& LukÁcs, Á. (2013). A specific patterns of executive dysfunctions in transcortical motor aphasia. Aphasiology, 27(12), 1426-1439.

Verbruggen, F., \& Logan, G. D. (2008). Response inhibition in the stop-signal paradigm. Trends in Cognitive Sciences, 12, 418-424.

Verbruggen, F., Logan, G. D., \& Stevens, M. A. (2008). STOP-IT: Windows executable software for the stop-signal paradigm. Behavior Research Methods, 40, 479-483.

Whitworth, A., Webster, J., \& Howard, D. (2014). A Cognitive Neuropsychological Approach to Assessment and Intervention in Aphasia: A Clinician's Guide. New York: Psychology Press.

\title{
THE IMPAIRMENT OF EXECUTIVE FUNCTIONS IN APHASIA
}

\author{
SZÖLLŐSI, IZABELLA - LUKÁCS, ÁGNES - ZAKARIÁS, LILLA
}

Background: Recent studies suggest together with language abilities executive functions can also be impaired in aphasia. Moreover, these functions can play a role in language processing. The purpose of our study was to investigate several executive functions - updating, response-based conflict resolution, and representational conflict resolution - in aphasia, and to explore the relationship between these functions and language performance.

Methods: Eight patients with aphasia with a lesion in the left frontal lobe, and eight healthy controls participated. To test executive functions, we used a Stop Signal, a Nonverbal Stroop, and an Nback task. We tested language processing with the TROG-H.

Result: Our results showed that response-based conflict resolution and updating working memory representations were both impaired in aphasia. Performance on comprehension of grammatical structures and updating working memory representations correlated at a trend level, but we did not find relationship between language comprehension and any of the inhibitory functions. 
Conclusion: In addition to language difficulties, injury of the frontal lobe areas is often associated with impairments of executive functions in aphasia - including response-based conflict resolution and updating processes. These executive deficits may also affect language processing.

Key words: executive functions, aphasia, inhibition, updating, language comprehension, working memory 